\title{
THE CONCEPT OF AN IDEAL PERSON IN WORKS OF ARISTOTLE
}

\author{
Valērijs Makarevičs \\ Daugavpils University, Latvia \\ Dzintra Iliško \\ Daugavpils University, Latvia
}

\begin{abstract}
The issue of a human person, and his/her development, and particularly in connection with a social sphere is extremely relevant for our times. In psychology, this issue has been developed through developmental periods, theories of personality identity and conditions that contribute to a self-actualization of an individual. In this regard, interest is how these ideas evolved in the process of cultural and historical development of humankind, how they were understood by previous generations of scientists and philosophers, how theoretical views of past generations are interpreted by the researchers of our time. This determined the objectives of this research. The authors applied the method of content analysis of the text with the aim to discover the concept of an ideal, or perfect person in works of Aristotle, to compare this concept with the corresponding views of Plato, to determine the influence of Aristotle's concept of an ideal person on modern theories of personality. The research method is a content analysis of works of Aristotle and research done by the authors that reflect a philosophical heritage of the Greek thinker. As for both, Plato and Aristotle, the soul is the basis of life and the source of human activity. For Plato the soul appears to be an indivisible and immortal entity, then for Aristotle it has its own structure. Human soul is capable of development and improvement. The main condition for improvement, according to Plato, are correct actions of a person from the point of view of law and public opinion. Aristotle believes that in this process, education and upbringing plays major attention. Aristotle's ideas today are being developed in a deep and humanistic psychology and developmental psychology.
\end{abstract}

Keywords: Aristotle, Plato, soul, an ideal (perfect) person.

\section{Introduction and Research Methodology}

The issue of a person and his/her development in connections with the social environment is extremely relevant for our time. In psychology, this issue has been developed through the developmental periods, theories of identity and conditions that contribute to a self-actualization of an individual. In this regard, interest arises how these ideas evolved in the process of cultural and historical development of a humankind, how they were understood by previous 
generations of scientists and philosophers, how theoretical views of past are interpreted by the researchers of our time.

The authors have repeatedly addressed this issue in previous research. Previous articles presented the results of the analysis of the works of the ancient Greek philosopher Plato, as well as the Byzantine philosophers - theologians. The main issue in these works was the question of a soul. All authors adhere to the idea that the soul is the source of human vital activity. The question of the origin and time of existence of the soul is debatable.

Plato reflects on two types of time: personal and mythological. Personal time coincides with the life time of a person. This is where the professional development of the individual takes place, or, when a professional identity is formed.

The formation of personal perfection (personal identity) is associated with a mythological time. This is due to two reasons. First, souls exist in a special, non-material world and enter the human body at the moment of his/her birth. At the moment of appearance in a human body, they already have the experience of past lives. This experience can be positive or negative. By the actions that one performs in one's life, a person can correct this experience both for better and for worse. Thus, personal identity depends on the life experience of previous generations to a large extent, and only partially on the efforts of the individual himself/herself.

Secondly, there is a genealogical history of souls. Souls originating from mythological gods - creatures perfect in nature - determine the characteristics of the behavior of great and noble people. Therefore, the existence of these souls can be called mythological (Makarevičs, 2012).

With the adoption of Christianity, Plato's idea of the connection between the process of human perfection and mythological time came into conflict with the principle of monotheism. The Byzantine thinker Gregory of Nyssa tried to resolve this contradiction. According to his views, the soul appears simultaneously with the body and does not have the experience of past lives. The human soul, according to Gregory of Nyssa, like Plato, is immortal. The souls of physically dead people make up the Pleroma, or the World Soul, what has a transpersonal character. The welfare of the immortal soul must be taken care of during life. This is ensured by the human striving for perfection, for God.

The main difference between the views of Gregory of Nyssa and Plato's views on the existential foundations of the existence of the soul is, therefore relates to fact that Platonic souls owe their initial perfection for many Greek gods. The subsequent generations may lose their perfect qualities. According to Nyssa, the soul appears in the body of a newborn at the same time of one's birth. The goal of a person's life is to actualize what is in him/her from God (Makarevičs, 2017a). 
In works of Byzantine philosophers-theologians, we can learn more and more about subjectivity, development of a person by his/her own efforts (Makarevičs, 2017b). Aristotle's works were created in a time continuum between Plato and Byzantine thinkers. This determined the objectives of this research that are the following:

To explore the concept of a perfect person (the best people, as defined by the Aristotle).

1. To identify social and psychological conditions conducive to the emergence of perfect people in the society.

2. Compare Aristotle's concept of a perfect person with the corresponding concept of Plato's works.

3. To explore which ideas of Aristotle are used in modern psychology of personality.

Research method used are: the content analysis of Aristotle and other authors' works.

\section{Aristotle's Concept of the Soul}

Ancient, Byzantine and medieval concepts of a person were based on the concept of the soul. Unlike Plato, the Aristotelian soul has no past. It is born simultaneously with the birth of a human child. The soul has several levels of manifestation: vegetable (responsible for physiological phenomena), animal (including a variety of psychological processes and personality traits, manifested in direct behavior) and reasonable level. The goal-setting activity of a person is provided by the highest, reasonable level of the soul (Aristotle, 1976).

Aristotle, unlike Plato, clearly structures the essential composition of the soul. If we compare the Aristotelian description of the structure of the human soul and the current ideas about the structure of mental phenomena, we can see an amazing similarity with the understanding of the structure of the inner world, which is accepted in modern psychology.

According to these ideas, the inner world, in particular, is represented by mental processes: sensation, perception, memory, thinking, imagination, emotions and feelings. The Aristotelian interpretation of the soul appears simultaneously with the birth of a person and does not have a mythological or phylogenetic past. These processes in their embryonic state appear already in the prenatal period, but they develop during person's life.

The soul is endowed with the ability to self-development. This ability is called entelechy. Entelechy manifests itself at the lower structural levels of the soul - plant and animal and does not contribute to the emergence of a perfect person. Only an intelligent part of the soul, endowed with the ability of selfdevelopment, can provide the conditions for the emergence of a perfect person. 
Reasonable part of the soul is the most difficult part for understanding of the essence of the whole integral soul in the interpretation of Aristotle. Unlike the first two levels, which appear simultaneously with the birth of a person, the third is a gift to a person from Higher Powers. This is a gift from Gods. In this part of the soul that is responsible for the emergent consciousness of a person, for the ability to make choices and the manifestation of volitional behavior to achieve the goals of life (Aristotle, 1976). As Rudneva notes, by Aristotle the mind is understood as the meaning and essence of the cosmos, in which a person is an inseparable part (Rudneva, 2007).

In his concept of the soul, Aristotele partially adheres to the views of his teacher, Plato. Brandon Look and several other scientists have noted, that the intelligence is immaterial or does not mix with the body. This allows to compromise Aristotle with Platonism (Look, 2007).

The age of the vegetable and animal parts of the soul is finite and is limited by the lifetime of the subject. The rational part of the soul has its own history, different from the subject, and it is immortal. According to Johansen, a researcher from Brasenose College (Oxford), this immortal active intelligence is the main component of the human soul, since it ensures the development of the individual on the path towards perfection (Johansen, 2012).

\section{Ideal Person as the Highest Level of Identity Development}

The foundations of the concept of an ideal person are set forth by Aristotle in his Nicomachean Ethics. Each person has is/her own purpose in life. Nevertheless, a person can consciously and voluntarily change his/her purpose, but not everyone is capable of this.

Every person, according to Aristotle, faces a choice of life path. Or, according to Aristotle, a way of life. Hedonistic, state or contemplative. the choice of the latter two is associated with virtues. The main virtue follow the other principle that means that in your actions, manifestations of feelings, decision-making, you should choose the middle option.

So, in the triad: cowardice - courage - recklessness, a perfect person has courage, and for recklessness is not associated with the reason given to man by God. The highest goal of life is happiness.

In the process of a formation of a person, his/her achievement of the highest goal is impossible without the influence of society, where the main factors are appropriate education and social ties (friendship) (Aristotle, 1997).

The analyses of the relationship between the individual and the personal in Aristotle's concept of a person, according to the philosopher Russell implies that individuality is determined by the characteristics of the irrational soul (including plant and animal parts). The personality of an individual is associated with the 
rational part of a soul. The irrationality divides people. The rational part of the soul serves as the basis for unification. The rational part of the soul contributes approaching God. This is facilitated by worthy actions and creativity of the individual. Individuality disappears with the death of a person. The person dissolves into the divine and thus becomes immortal. .....An ideal person is a person who is dissolved in the divine and, therefore, does not exist as a person (Russell, 1994). These ideas of Aristotle are illustrated by the words of A.S. Pushkin:

No, all of me will not die. Soul in the cherished lyre,

My ashes will survive (Pushkin, 1836).

The greatest virtue is only possible for the few. As J. Dudley notes, the requirement of a fulfilled life implies a holistic development of a person and the achievement of perfection, or completeness. An indicator of the correctness of the chosen life path makes the experience of happiness. But happiness, according to Aristotle, is not the goal of life. It is a kind of barometer that measures the degree of success (intermediate to goal achievement).

Aristotle draws a parallel between the life of God and the ideal life of a person. The basis is intelligence, since the nature of God relates to intelligence (Dudley, 2017).

But about what kid of God does Aristotle writes about? Is it the God who lived in the era of polytheism? M. Mamardashvili tried to solve this riddle. He wrote: "This is the idea of infinity. Let us imagine a more concrete image, without which, the ancient Greeks dispensed with in such cases, since they were not Christians. Let's call this infinity God ... And our ability to think about it is the manifestation of God in us" (Mamardashvili, 1997, 140).

In earthly life, the ideal person is an individual who is proud, does not belittle his dignity, and despises anyone who is truly worthy of contempt (1124b). B. Russell, comments on this thought of Aristotle, by explaining that Aristotle's description of a proud and generous person is very interesting, as it covers the meaning in which Nietzsche's view of Christianity as a slave is justified.

The Christian ethics disapproves the notion of pride, which Aristotle considers a virtue, and praises the humility in which Aristotle sees a vice (Russell, 1994, 177-179).

The special role of ideal people is associated with the state and politics. The stability of the state depends on the quality of government and the policy it pursues. As A. Lonin notes, the main feature of "ideal people" is the presence of their political voices (Lonin, 2010). But can everyone participate in the governance of the State? Among the capable individuals of governance, Aristotle excludes slaves. He also excludes women, since men have power over them. Therefore, they are dependent on others. Only free people are suitable for 
the governance and political life (Aristotle, 2011). And here one more question to be asked: is every free person capable of performing a function in the government?

According to Aristotle, a person inherits the experience of past generations (as an intelligent part of the soul). But this experience needs to be developed and actively applied in virtue-oriented behavior. In this regard, it is interesting to refer to V. Sukhachev. He wrote that the term arete is traditionally translated as virtue. Arete can also be translated as the ability to own one's life, one's thinking, and actions (Sukhachev, 2017).

Thus, following the virtues in one's actions, contributes to the development of subjectivity, - the ability of the individual to determine and plan his/her own life. But this development of subjectivity is possible only with an appropriately organized education and upbringing of the younger generation. At the same time, an extremely important role in the upbringing of "ideal people" belongs to a woman. Ann Ward, via the analyses of the role of the mother in the upbringing of "ideal people" in the work of Aristotle's Nicomachean Ethics, notes about a special role of friendship in the social relations of such people. The first lessons of selfless friendship are gained in the early childhood in the process of communication with the mother (Ward, 2008).

\section{Influence of Aristotle's Ideas on Subsequent Concepts of the Ideal Person}

As L. Tonoyan wrote, Aristotle's concept of an ideal person was not popular in Antiquity, but had a significant impact on the development of ideas about a person in the Middle Ages (including the views of Byzantium theologians) (Tonoyan, 2017).

We can trace the development of his ideas in humanistic psychology. Contemporary depth psychology includes classical psychoanalysis, Jung's analytical psychology, Adler's individual psychology, and contemporary trends (such as Hillman's archetypal psychology). Depth psychology examines the processes occurring in the sphere of the unconscious and their influence on human behavior and thinking.

As for the depth psychology, we can see the development of Aristotle's ideas in works of Adler and Jung. Adler believes that a sense of community is essential for the holistic development of a person.

It is innate and allows a person to engage in positive social relationships, to act for the benefit of other people, to help, and not to manipulate them. A person can lose a sense of community as a result of unproper upbringing. Thus, the preservation of this feeling depends entirely on the relationship that develops between the child and the mother in the first years of his/her life. But the sense of community in Adler's understanding is nothing more than the concept of 
friendship by Aristotle and the influence of the first years of a child's life for the acquisition and strengthening of this ability (Adler, 1997).

Further, for the analyses of works of Aristotle, Litvinova wrote: if a man wants to be captivating, he must borrow grace and tenderness from women, and if a woman wants to win hearts, she must have a certain amount of courage (Litvinova, 2016). In other words, here we see two principles of life: male and female. In this case, the masculine principle should be balanced by the feminine, and the feminine -by masculine. We find the development of these ideas in Jung's concept of the Anima and the Animus (Feydimen \& Freiger, 1994).

The idea of entelechy, or the soul's capacity for self-development, underlies Maslow's understanding of the phenomenon of self-actualization. Maslow is one of the founders of humanistic psychology. Self-actualization is the desire of a person to maximize his/her abilities and a creative potential in life. The need for self-actualization, according to Maslow, is the highest level in the hierarchy of human needs. As the author refers, at the moment of self-actualization, the individual is wholly and completely human. This is the moment when One realizes oneself (Maslow, 1967). So Maslov, in his characterization of the "best" people, following Aristotle, attaches decisive importance in their formation to entelechy, or the ability of the soul for a self-development.

\section{Discussion and Conclusions}

The authors present a comparison of concepts of the ideal person in Plato and Aristotle. Since "ideality" in one and the other concept is a special ability of the soul, the authors carries out a comparative analysis of these abilities, as well as the personal qualities of a person produced by these abilities. The authors used the same comparative scheme that they used when they carried out a comparative analysis based on the works of Plato and the Byzantine Gregory of Nyssa (Makarevičs, 2017a) that is reflected in Table 1.

To summarize, for both, Plato and Aristotle, the soul is the basis of life and the source of human activity. For Plato the soul is an indivisible and immortal immaterial entity, but for Aristotle it has its own structure. Moreover, only the highest part of it - the intelligent - has immortality.

The human soul is capable of development and improvement. The main condition for improvement, according to Plato, is correct, from the point of view of law and public opinion, the actions of the person himself. Paying tribute to the activity of a person, Aristotle believes that teaching and upbringing, relations with the mother in early childhood, play an important role in this process. In what both authors are unanimous, it is that the approach to the ideal traits of a person. 
Table 1 Comparative Analysis of the Abilities of the Soul and the Characteristics of Ideal ("best") People Produced by These Abilities in Plato and Aristotle

\begin{tabular}{|c|c|c|}
\hline Criterion & Plato & Aristotle \\
\hline $\begin{array}{l}\text { Social - historical conditions } \\
\text { for the creation of the } \\
\text { concept }\end{array}$ & $\begin{array}{l}\text { Paganism } \\
\text { (Polytheism) }\end{array}$ & $\begin{array}{c}\text { Paganism } \\
\text { (Polytheism; but in his works } \\
\text { Aristotle uses the name of } \\
\text { God in singular) }\end{array}$ \\
\hline Functions of the soul & $\begin{array}{l}\text { Determines the activity of a } \\
\text { person, serves as the basis for } \\
\text { his/her improvement }\end{array}$ & $\begin{array}{l}\text { Determines the activity of a } \\
\text { person, serves as the basis for } \\
\text { his/her improvement. }\end{array}$ \\
\hline $\begin{array}{c}\text { Temporal characteristics of } \\
\text { the soul }\end{array}$ & $\begin{array}{l}\text { At the moment of } \\
\text { embodiment in the human } \\
\text { body, the soul already has the } \\
\text { experience of past lives }\end{array}$ & $\begin{array}{l}\text { The soul has a complex } \\
\text { structure and consists of } \\
\text { three substructures. The first } \\
\text { two appear at the moment } \\
\text { when the body is born and } \\
\text { disappear with the death of } \\
\text { the body. The third, sentient, } \\
\text { is timeless and immortal. }\end{array}$ \\
\hline $\begin{array}{l}\text { "Start up" conditions for the } \\
\text { development }\end{array}$ & $\begin{array}{l}\text { Strat up conditions are not } \\
\text { similar for all people. They } \\
\text { depend on the past } \\
\text { experiences of the soul. }\end{array}$ & $\begin{array}{l}\text { Not the same. Depends on } \\
\text { the origin and gender of the } \\
\text { person. }\end{array}$ \\
\hline $\begin{array}{l}\text { The dependence of the } \\
\text { content of the soul on human } \\
\text { actions }\end{array}$ & Immediate & $\begin{array}{l}\text { Mediated by the training, } \\
\text { upbringing and experience of } \\
\text { the first years of life, an } \\
\text { ability called entelechy. }\end{array}$ \\
\hline $\begin{array}{l}\text { The work of a person with } \\
\text { his/her own soul with the aim } \\
\text { to improve }\end{array}$ & Discrete & $\begin{array}{l}\text { Discrete, but only applicable } \\
\text { to the reasonable part of it. }\end{array}$ \\
\hline $\begin{array}{l}\text { The connection between a } \\
\text { person and a society }\end{array}$ & $\begin{array}{l}\text { The stability of the State } \\
\text { depends on the extent to } \\
\text { which its rulers are able to } \\
\text { follow the principle of good. }\end{array}$ & $\begin{array}{c}\text { The stability of the state } \\
\text { depends on how its elite } \\
\text { meets the criteria of "ideal } \\
\text { people" }\end{array}$ \\
\hline $\begin{array}{l}\text { Personal development and } \\
\text { development of a personality }\end{array}$ & $\begin{array}{l}\text { Personal improvement } \\
\text { negates individuality. At the } \\
\text { end point of development, } \\
\text { individuality disappears. }\end{array}$ & $\begin{array}{l}\text { Personal improvement } \\
\text { negates individuality. But } \\
\text { individuality is preserved as } \\
\text { a difference in the character, } \\
\text { abilities and manifestations } \\
\text { of the lower levels of the soul } \\
\text { (animal as anatomy of the } \\
\text { body) }\end{array}$ \\
\hline
\end{tabular}

Aristotle's ideas were developed in many modern psychological concepts. The idea of entelechy is in the concept of a self-actualizing person used by Abraham Maslow. The idea of the presence of masculine and feminine 
principles in a person's personality is in the concept of Anima and Animus is used by Carl Jung. The idea of the importance of the relationship between the child and the mother for further personal development and the acquisition of identity is used in various periods of human development.

\section{References}

Adler, A. (1997). Nauka zhitj. Kiev: Port-Royal.

Aristotle. (1997). Nikomahova etika. Moskva: EKSMO Press.

Aristotle. (1976). O dushe. Moskva. Mislj.

Aristotle. (2011). Politika. Moskva: Astrelj.

Boeri, M. D. (2018). Plato and Aristotle On What Is Common to Soul and Body. Some Remarks on a Complicated Issue. In M. D. Boeri et al. (Eds.), Soul and Mind in Greek Thought. Psychological Issues in Plato and Aristotle, Studies in the History of Philosophy of Mind, (pp. 153-176), Springer International Publishing.

Dudley, J. (2017). The physical and metaphysical foundations of ethics for Aristotle. VERBUM, 19, 9-23.

Feidimen, Dzh., Freiger, R. (1994). Lichnostj i lichnostnij rost. Vipusk 1. Moskva: Moskovskij otkritij universitet.

Johansen, T. (2012). The Powers of Aristotle's Soul. Oxford: Oxford University Press.

Litvinova, A.F. (2016). Aristotle, ego zhiznj, filosofskaja I nauchnaja dejateljnostj. Predislovie. Aristotle. Politika. Grupa konpanij „RIPOL klasik”. Retrived from https://www.litmir.me/br/?b=577105

Lonin, A.,V. (2010). «Luthshie ljudi» i ih rolj v razvitii obshchestva v sisteme vzgljadov Plato i Aristotle. Uspehi sovremennogo estestvoznanija, 9, 234-236.

Look, B. (2007). Aristotle's De Anima. Retrieved from https://www.uky.edu/ look/Phi\%20260\%20Aristotle\%27s\%20De\%20Anima.pdf

Makarevičs, V. (2017a). Comparative analysis of the perfect human in the writings of Plato and Gregory of Nyssa. Rural Environment. Education. Personality. (REEP). Proceeding of the 10th International Scientific Conference, 10, Jelgava: Latvia University of Agriculture, 121-126.

Makarevičs, V. (2017b). Evolution of views on human development in the works of Byzantine philosophers-theologians. Daugavpils Universitātes 59. Starptautiskās zinātniskās konferences rakstu krājums. B dal̦. Sociālās zinātnes. Daugvapils: Daugavpils Universitātes Akadēmiskais apgāds „,Saule”, 168-175.

Makarevičs, V. (2012). The problem of personality and professional identity in Plato’s works. Proceedings of the $53^{\text {th }}$ International Scientific Conference of Daugavpils University. Daugavpils: Daugavpils University. Retrieved from: https://www.dukonference.lv/ lv/content_53 (15.07.2019).

Mamardashvili, M. (1997). Lekcii po antichnoj filosofii. MODKVA: AGRAF.

Maslow, A. H. (1967). Self-actualization and beyond. In J. F. T. Bugental (Ed.), Challenges of humanistic psychology (pp. 278-286). New York, NY: McGraw-Hill.

Pushkin, A.S. (1836). Ja pamjatnik sebe vozdvig nerukotvornij. Retrieved from https://ilibrary.ru/text/797/p.1/index.html

Rassel, B. (1994). Istorija zapadnoj filosofii. Kn.1. Novosibirsk: Izdatelstvo Novosibirskogo universiteta. 
Rudneva, E.G. (2007). Antropologicheskie i pedagogicheskie idei Aristotle. Gumanitarnie nauki: teorija i metodologija, 3, 105-108.

Sukhachev, V. (2017). About the out-of Moral interpretation of some basic „moral” concepts of „Nicomachen ethics,” VERBUM, 19, 52-56.

Tonoyan, L. (2017). Ten Categories of Aristotle and Ten Commandiments of Moses. VERBUM, 19, 78-88.

Ward, A. (2008). Mothering and the sacrifice of self: Women and friendship in Aristotle's Nicomachean Ethics. Third Space: A Journal of Feminist Theory and Culture, 7(2), 32-57. Retrieved from https://journals.sfu.ca/thirdspace/index.php/journal/rticle/view/ ward/102 